bureaucracy, have been inconspicuous in the East. They should swallow their pride and use the Soros mechanism instead. So have been universities in the West. Yet one of the hopeful developments in Russia is the government's new determination to strengthen the capacity of the public universities for research, much along the Western model. That should be a sign to universities elsewhere, especially those in Europe, that the time has come to forge new links in the East.

What will come of all this? It would be wrong to expect too much. Governments and institutions in the West are all too ready to proclaim that they, too, have problems occasioned by the ending of the Cold War. The difference, of course, is that the problems of Russian research are at once more serious and more likely to have permanent consequences. But why bother, if the most able people have already moved West? There are two kinds of answers. First, if nothing substantial is done, the scientific enterprise as a whole will be harmed. Second, the political benefits of a more enlightened Western view of Russian science could ultimately be substantial, as Russia's weekend diplomatic coup in Bosnia should have emphasized. It will be ironical if the only substantial recognition of this need is that of a man (Soros) whose wealth derives in part from spotting when governments follow unrealistic monetary policies.

\section{New ways to a PhD}

The British government is insufficiently radical in its proposals for revamping the PhD.

NoBody can accuse the British government of inaction, at least where the education of the young is concerned. Fresh from the regulation of the curriculum on religious education (see Nature 367, 496; 1994), it is now hoping to lay down the law on entry to $\mathrm{PhD}$ courses, at least for students seeking public support (see page 674). To be sure, the proposals are neither unexpected - they were advertised in last year's policy statement on research - nor exceptionable. The idea that there should be a prequalifying year for intending $\mathrm{PhD}$ students is the norm in France, for example, where the DEA is arguably the most competitive of public examinations.

The defects of the extra year now proposed for Britain are partly that it aims to kill too many birds with one stone. Will it be feasible, even in an extended academic year of 42 weeks, to give young people a deeper knowledge of their chosen discipline, a broad knowledge of cognate disciplines and "transferable skills and knowledge" likely to be valuable in careers outside universities while engaging 60 per cent of their time on research? But there is also every likelihood that the effect of the prequalifying year for publicly supported students will be to reduce the number of people eventually graduating with a $\mathrm{PhD}$. To be sure, the government now says that it will be for the research councils to decide how much of their resources to put into research training, but the demand for research grants proper will probably ensure that, with a stagnant budget, there will be no extra for students. For a country as short of high-level skill as Britain, that is not a joke.

In the circumstances, the Office of Science and Technology (OST) could with advantage have been more adventurous. One of the anomalous features of the present British arrangements for $\mathrm{PhD}$ training is that some university departments are awarded a quota of research studentships which they can then fill with candidates of their own choice. OST implies, in its consulation paper, that this system will remain in place, but that the research councils will be expected to monitor a system for the assessment of students singled out for admission to $\mathrm{PhD}$ courses. That is only logical, but it will not avoid some obvious abuses of the present system (among which are academic incest and the engagement of research students on projects made up to keep them occupied).

Why not instead abolish the quota system? That is the preferable course, especially when the number of universities has been greatly increased (by the accession of the former polytechnics to university status)? And why not at the same time ensure that $\mathrm{PhD}$ students are always engaged on meaningful projects by linking public support for research students (they are paid a pittance, and their host departments a similar amount) to the award of research grants for successful projects? That way, a person with a good idea could expect not merely to be awarded research expenses, but also some of the (admittedly untrained) manpower required to carry it through.

There would be objections from the universities, of course. Studentship quotas are jealously regarded and fought over, for example. More to the point, universities may reasonably argue that it is for them, and not for the research councils, to appoint students to their rosters. But there would be no substantial difference from the present system if it were left to successful grant applicants and their heads of department to select those employed. Indeed, if there is to be a national system for the prequalification of $\mathrm{PhD}$ students in Britain, there should be a wider spectrum of young people from whom to choose. Then the universities' complaint that $\mathrm{PhD}$ students must not be over-constrained by research targets is countered by the simple observation that British universities are well used to registering research assistants financed by grants for a $\mathrm{PhD}$.

Such a switch would also have positive virtues. Not least, it would enable universities without strong research departments to provide prequalification courses for their students, in the expectation that some of them would be able to embark on $\mathrm{PhD}$ courses elsewhere. And it would enable the research councils, without taking cosmic policy decisions, to begin paying graduate students respectably. That would be good for everybody's self-respect. And no harm would come from the increased length of time spent on winning a $\mathrm{PhD}$. The British university system, in which most students earn a first degree in three years and $\mathrm{PhD}$ in a further three, is now a kind of academic forcing-house. If each phase took an extra year, the remedial measures now planned would not be necessary. That would cost the government more, but so will the remedial measures. It would be better to bite that bullet now, not later. 